\title{
The Kopassus Dilemma: Should Australia Re-engage?
}

\begin{abstract}
Alan Dupont
$\mathrm{A}$ ustralian governments of both political persuasions have been embroiled in controversies over military cooperation with Indonesia since bilateral defence relations first began to gather steam under the Keating Labor government in the early 1990s. Prime Minister Paul Keating and Foreign Minister Gareth Evans were enthusiastic proponents of building strong ties with Indonesia, a policy which was extended to the military sphere with the establishment of two high level committees to coordinate and develop defence cooperation in 1994 (Ball and Kerr, 1996:70). These committees were later incorporated into an expanded defence agreement by the newly elected Howard Government in 1996, leading to the establishment of five working groups covering logistics, science and technology, communications, interoperability, education, training and exchanges (Walters, 1996:3).

But engagement with the Indonesian Special Forces (Komando Pasukan Khusus - Kopassus) has been especially contentious because of the well documented involvement of this elite Army unit in human rights abuses and some of the more egregious excesses of the Soeharto regime. It was a special forces unit under the command of Captain Yunus Yosfiah (later a minister in the Habibie government) that murdered five Western journalists at Balibo, East Timor in November 1975 (Ball and McDonald, 2000:100-13), while dozens of Islamic activists were killed in an ostensible government crack down on criminals at Tanjung Priok, a decade later (Schwarz, 1994:181; Vatikiotis, 1993:128); and Pathoni, 2002:13). Special forces 'black ninja' have also regularly terrorised rural communities throughout the archipelago for political and pecuniary reasons in a perversion of their national security role.

Concerns about the utility and morality of developing links with Kopassus were temporarily put to rest when bilateral defence cooperation was suspended in the wake of Indonesia's ignominious withdrawal from East Timor in 1999. But the Bali bombing in October, 2002 and the heightened security focus on terrorism in Australia have stimulated calls for a resumption of ties with Kopassus as the principal agency in Indonesia vested with responsibility for counter terrorism. For example, Defence Minister Robert Hill cautiously endorsed renewed ties, subject to the significant qualification that Australia would only deal with Kopassus's counter terrorist unit (Martin, 2002:5). Opponents have rejected the idea, however, primarily on human rights grounds, but also because Kopassus is believed to have given aid and succour to the very terrorist groups it is supposed to be fighting. In December 2002, for example, Shadow Minister for Foreign
\end{abstract}

Alan Dupont is Senior Fellow and Director, Asia Pacific Security Program, Strategic and Defence Studies Centre, the Australian National University. 
Affairs, Kevin Rudd, claimed that there were 'clear links between Kopassus and the Islamic terrorist organisation, Laskar Jihad' (Office of the Shadow Minister for Foreign Affairs, 2002).

\section{What is Kopassus?}

Given the extent to which terrorist groups have entrenched themselves in the archipelago, cooperation with Kopassus clearly has the potential to become a vexatious issue for the Howard government, with important ramifications for national security policy, counter-terrorism and relations with Indonesia. For these reasons it warrants a more considered assessment than the cursory and emotionally charged exchanges that have characterised much of the public debate so far.

An essential first step is to dispel several misperceptions about the role and modus operandi of the elite 5,000 strong Special Forces, and to understand where the organisation fits in the overall structure of Indonesia's Armed Forces (TNI). Kopassus is typically cast as a shadowy force that often operates outside the military chain of command and specialises in dirty tricks, covert intelligence gathering, and activities that could be loosely described as regime maintenance. Since President Soeharto's demise, Kopassus has also been accused of banditry, warlordism and a multitude of nefarious criminal practices ranging from illicit timber felling to sabotage, contract killings and drug running (see, for example, Kingsbury, 2002:71). Some of these accusations are undoubtedly true, but it would be a mistake to think of Kopassus only, or even primarily, in these terms.

The Special Forces is also the best trained, resourced and disciplined unit in the armed forces, and its officers have traditionally been among the most able, as evidenced by the disproportionately high number who have risen to senior command. Two notable examples are Generals Edi Sudradjat and Feisal Tanjung, both of whom later became armed forces commanders and, in Sudradjat's case, Minister for Defence. The current Army Chief, General Ryamizard Ryacudu, is a former Kopassus commander, as are two current cabinet ministers: head of the National Intelligence Agency (Badan Intelijen Negara, BIN), Lieutenant General (ret) A. M. Hendropriyono, and Transport Minister, Lieutenant General (ret) Agum Gumelar. In recent years, however, the ratio has fallen, largely because the unit's image has been tarnished within TNI itself.

At one time Kopassus was the unit of choice for aspiring young officers, and its esprit de corps is still second to none within TNI (Haseman, 2002:34). Like Australia's Special Air Service (SAS) regiment, Kopassus is responsible for intelligence collection, small unit operations and training other elements of the armed forces in specialised military and intelligence skills. The Special Forces are configured for rapid deployment to trouble spots anywhere within the archipelago, as well as overseas. Kopassus also has a counter insurgency and counter terrorist role that is typical of special forces throughout the region (see Lowry, 1996:86-89 on the structure and role of Kopassus). Counter Terror Unit 81 (Satuan Gulangan 81 - SG 81), named in part after a successful 1981 operation against the hijackers of a Garuda Airlines flight in Bangkok, is organic to Kopassus. Headquartered in 
Jakarta, SG 81 has played a significant role in locating and apprehending the terrorists responsible for the Bali bombing (Haseman, 2002:35).

Unfortunately, these legitimate functions have been distorted and corrupted by venal politicians and ambitious career officers who have manipulated the unit for personal gain by exploiting the intense personal loyalties that bond the Special Forces brotherhood. The politicisation of Kopassus reached its nadir in the mid1990s under Lieutenant General Prabowo Subianto, former president Soeharto's son in law, who used the organisation as a de facto praetorian guard. In this respect, Kopassus is a microcosm of TNI. Unsurprisingly, there is a strong view among Indonesia's ruling elite and growing middle class that Kopassus ought to be depoliticised and made more accountable to civilian control. But it is difficult to see how this worthy objective can be achieved as long as TNI obtains more than half its budget from running private businesses, a bifurcation which encourages a culture of guns for hire. While not atypical for a developing country, the business interests of the Indonesian military are extensive and embedded (for an analysis of TNI funding and structural weaknesses see Dupont, 1996:284-86). Some of the money comes from military foundations and holding companies in which TNI has a stake, such as banks, hotels and real estate (McBeth, 2002:201). More worrying is the increasing involvement of Kopassus personnel in brigandry, extortion, illegal logging and protection rackets.

After a brave but ill-directed attempt by former president Abdurrachman Wahid to remove TNI from politics and make the armed forces more transparent and accountable, military reform seems to be off the government's agenda. In recent years, TNI has begun to reassert itself as traditional patronage and money politics has reemerged with a vengeance. The weak and factionalised government of Megawati Sukarnoputri has become heavily reliant on TNI support, and is likely to remain so as the 2004 elections approach. Decentralisation of political and economic power has reduced Jakarta's control over the activities of the military in general, and Kopassus in particular, so that it is becoming increasingly difficult to determine whether Kopassus transgressions are the result of local initiatives or national policy. Furthermore, it is not always clear to what extent senior TNI commanders are in the command loop. The armed forces' sullied reputation makes it an easy and obvious scapegoat for virtually any unexplained incident that smacks of clandestine or organised illegal activity. But the reality is more complex and ambiguous than critics of the military sometimes allow.

The assassination of Papuan independence leader, Theys Eluay, in November 2001 is a case in point. Although there is strong circumstancial evidence that Eluay was killed by special forces personnel, the motive for his killing and the culpability of senior TNI and Kopassus officers is unclear. So is the extent of military support for terrorist groups. Much has been made of Kopassus links with the notorious Laskar Jihad, which fomented and aggravated the inter-communal violence that devastated Maluku and parts of Sulawesi. Most of the military training and support, however, seems to have been provided by a small group of TNI officers, with pro-Islamic leanings, not all of whom have Kopassus backgrounds or associations. The senior officer most often associated with Laskar 
Jihad is Lieutenant General Djadja Suparman, a former commander of the Army Strategic Reserve (Kostrad). Sceptics may argue that this is moral hair splitting. But there is an important difference between institutional support for a nationally agreed policy and freelance operations conducted by former and serving military personnel for ideological and political reasons or personal gain.

Australia will find it difficult to pick and choose its Indonesian partners according to some arbitrarily determined moral standard. Moral foreign policies are fine in principle, but fraught with practical difficulties. Aside from the obvious and unanswerable question of whose moral standards should apply, Jakarta is unlikely to accept a sectoral approach to defence relations whereby Kopassus is quarantined or kept at arm's length (Munro, 2002). Any attempt by Canberra to pursue such a policy would inevitably raise questions about the sustainability of the bilateral relationship, and reinforce perceptions in some quarters of the region that the Howard government is arrogant, patronising and lacking in understanding of political realities in Indonesia. Moreover, while bilateral police cooperation post-Bali has exceeded expectations, Kopassus is still Indonesia's pre-eminent counter-terrorist organisation, and will naturally expect to be involved in any collaborative arrangements to deal with future terrorist incidents. Those who argue that Australia's counter-terrorist cooperation should be confined to the Indonesian police ignore this reality and evince a well meaning, but ill conceived, moral relativism. The police are hardly paragons of virtue, just as Kopassus is not the personification of all evil. Both are products of the same security establishment, and mirror the strengths and weaknesses of the Indonesian state.

\section{Obstacles to Cooperation}

Nevertheless, the critics of engagement have a case. No Australian government, whatever its complexion, can ignore Kopassus's past abuses or its poor professional image - as both the Coalition and Labor have found to their cost. Indonesian liberals are also distrustful of Kopassus and see it as the epitome of all that is wrong with the armed forces. The problem for the Howard government is that most of the Australian media and public will oppose comprehensive engagement with Kopassus unless there is convincing evidence that the organisation is seriously committed to reform.

Laskar Jihad's purported disbandment, announced with great fanfare in October, and progress on bringing to an end long-running strife in Aceh, Sulawesi and Maluku, will reduce the opportunities for mischief making by Kopassus for the time being at least. But the hiatus may be short-lived, for there are no guarantees that any of the recently signed peace agreements will hold. And there are worrying signs that the special forces leadership has switched its attention to the province of Papua, where pro-Indonesian militia activity is on the increase. Unlike East Timor, Indonesian conservatives and liberals are united in their view that Papua is an integral part of the nation and cannot be allowed to secede. Kopassus may therefore be given a free hand to repress internal dissent, along 
with a licence to 'protect' Muslim settlers against perceived Christian provocations and to root out supporters of the independence movement. An outbreak of sectarian violence in Papua in which Kopassus is complicit would seriously complicate the Howard government's attempt to establish close working ties with the red berets.

Although the spectre of future terrorist outrages provides opportunities for enhanced Australia-Indonesia security cooperation, there is a risk that TNI could manipulate the situation for political advantage and inadvertently inflame, rather than douse, the smouldering fires of Islamic fascism. It is clear that the generals are awake to the possibilities that the war against terrorism provides for advancement of their own personal agendas as well as TNI's institutional interests. The head of Indonesia's National Intelligence Agency, Lieutenant General (ret) A. M. Hendropriyono, a former Kopassus officer, has succeeded in having himself appointed as Indonesia's counter-terrorist intelligence czar. Another retired general, Susilo Bambang Yudhoyono, the Coordinating Minister for Politics and Security, maintains responsible for policy.

Of course it would be perverse to deny the military a prominent role in counter-terrorism, as it is one of only two organisations in Indonesia specifically equipped and resourced for the task. (The other is the police, which is poorly resourced by comparison, and has only a limited capacity for strategic intelligence collection, forensic investigation and consequence management.) However, the game is not just to kill terrorists. They must be denied the political space to recruit new acolytes and spread their message of hate. An over-reliance on military instruments to prosecute the war against terrorism could prove quite counterproductive, especially if Kopassus were left to its own devices. As Paul Monk observes, far from stamping out radical Islamic thought in the late 1970s, the Shah of Iran's secret police actually facilitated the anti-regime activities of the Ayatollah Khomeini by its ruthless repression of dissent. SAVAK's behaviour only served to reinforce the view among ordinary Iranians that the real enemy was not the Ayatollah but the security forces and their Western backers (Monk, 2002).

\section{Tailored Engagement}

This brief analysis provides some sense of the dilemma Canberra faces in its stated desire to work more closely with Indonesia at a time when Australia is demonstrably threatened by the spread of Islamic terrorism in Southeast Asia. Australia is not alone in having to weigh its security concerns against its commitment to human rights. Other democracies confront a similar quandary in deciding whether or not to engage Kopassus, given the organisation's questionable human rights record and involvement in acts of terrorism and extra-judicial killings. Nonetheless, engagement can be justified on three grounds. First, in the new, more threatening strategic environment that Australia faces it is imperative that the opportunities for effective security cooperation with our regional neighbours are maximised. Second, Kopassus is a highly capable, well-trained force that is an integral part of Indonesia's counter-terrorist machinery, and it 
would be counterproductive to exclude the special forces from bilateral initiatives to combat terrorism in Indonesia.

Third, strong personal ties between the Australian Defence Forces and their TNI and Kopassus counterparts are not only crucial to an effective regional counter-terrorist strategy, but are also essential to the long term health of the Australia-Indonesia relationship. The outstanding and unprecedented joint operation between the Indonesian National Police (POLRI) and the Australian Federal Police (AFP) in successfully pursuing the perpetrators of the Bali bombing was due, in large part, to the personal rapport established over a number of years between senior AFP and POLRI officers (AFP Commissioner, Mick Keelty, and the head of the Indonesian police investigating team, I. Made Pastika, were both students together at the AFP's 1993 Management of Serious Crime Course in Canberra). That said, Australian engagement should not be unqualified. We need to use what influence we have to encourage TNI to resume the stalled reform agenda and work towards the goal of a more accountable, professional and apolitical military force. This should be done in conjunction with like-minded countries, but in a way that does not offend Indonesian sensibilities and recognises that the pace of reform is likely to be slow and uneven. If Australia eschews security cooperation with TNI, our ability to shape its responses and resist the spread of Islamic fascism in Indonesia and the immediate neighbourhood will be greatly diminished.

Of course the war against terrorism must be fought on a broad front. Military action is not a substitute for an imaginative and broadly conceived strategy that addresses the poverty and social alienation that are root causes of terrorism. Nonetheless, preventive measures and consequence management (that is, handling terrorist acts once committed) are an intrinsic part of any effective counter terrorist strategy, both nationally and regionally. By definition, the military must be involved as one of the key institutions vested with responsibility for counterterrorism. This is especially so in developing states like Indonesia, where the armed forces dominate the security sector and are political actors as well. Quarantining or marginalising Kopassus is unachievable in practice, and would be ultimately self-defeating. Such a policy would alienate not just Kopassus but the whole of TNI, and would have negative consequences for Australia-Indonesia relations - certainly while Megawati remains president.

Police cooperation is a quintessential part of the security mosaic, and there is much more that Australia could do to assist the Indonesian police to build capacity in the crucial areas of forensic investigation, technical intelligence collection, and victim and bomb identification. Indeed, police cooperation post-Bali has been exemplary, and is a model for other forms of collaborative activity with the Indonesian security establishment, including Kopassus. But those who contend that our bilateral counter-terrorist cooperation should be confined to the police miss the point. The police do not have the authority, expertise or resources to control all aspects of counter terrorism in Indonesia, nor should they. Robbing Amirul to pay Dai would drive a wedge between TNI and the police, and would impede the development of trust and collegiality. 
A more productive approach would be to pursue a policy of tailored engagement - entailing a multi-dimensional approach to security cooperation with Indonesia that includes, rather than isolates, Kopassus, and focuses on joint operations and intelligence gathering against Jemaah Islamiah and other fundamentalist groups. Australia's SAS could be authorised to resume training assistance to the counter terrorist arm of Kopassus, SG 81. But a better option might be to encourage Indonesia to pursue the idea of creating a new joint counter-terrorist task force. Ideally, this would bring together the police, SG 81 and other elite military units such as the Air Force Special Forces Unit (Paskas) and special elements of the Marine Corps (Haseman, 2002:35).

The virtue of this approach is that it would provide a more politically palatable, but still workable, framework for cooperation with Kopassus, which could be extended to other areas of the defence relationship over time. In this way Australia could advance two important strategic objectives that until now have been seen as mutually incompatible - collaborating with Kopassus in support of our defence and national security interests, while continuing to encourage political and military reform as part of a broader agenda to entrench democracy and the rule of law in Indonesia. Excluding Kopassus because of its human rights record provides no incentives for good behaviour. A policy of tailored engagement, on the other hand, will create opportunities for leverage and influence that can only come through personal contact and sustained habits of dialogue. The ball is in Australia's court.

\section{References}

Ball, D. and P. Kerr, (1996), Presumptive Engagement: Australia's Asia-Pacific Security Policy in the 1990s, Allen \& Unwin in association with the Australian Foreign Policy Publications Programme and the Department of International Relations, RSPAS, ANU, Canberra.

Ball, D. and H. McDonald (2000), Death in Balibo Lies in Canberra, Allen \& Unwin, St. Leonards, NSW.

Dupont, A. (1996). 'Indonesian Defence Strategy and Security: Time for a Rethink?', Contemporary Southeast Asia 18:3, December.

Haseman, J. (2002), 'Kopassus: The Good and the Bad', Asia-Pacific Defence Reporter, 28:9, November.

Kingsbury, D. (2002), 'Australia Gets Off on the Wrong Side in Jakarta', The Australian Financial Review, 24 October.

Lowry R. (1996), The Armed Forces of Indonesia, Allen \& Unwin, St. Leonards, NSW.

Martin, C. (2002), 'Australia "Needs Kopassus Link”, The Australian Financial Review, 11 November.

McBeth, J. (2002), ‘The Army’s Dirty Business', Far Eastern Economic Review 7, 20-21 November. 
Monk, P. (2002), 'Silly, Mr. Downer? Keep Thinking', The Australian Financial Review 1 November (Review Section:4).

Munro, C. (2002). 'Kopassus a Thorny Issue for Australia', Canberra Times, 12 November:9.

Office of the Shadow Minister for Foreign Affairs (2002), 'Howard Government all Over the Place on KOPASSUS Links', Media Release, 12 November.

Pathoni, A. (2002), 'Kopassus in Frame Over Ambush', Sydney Morning Herald, 15 November.

Schwarz, A. (1994), A Nation in Waiting: Indonesia in the 1990s, Allen \& Unwin, St. Leonards, NSW.

Vatikiotis M. (1993), Indonesian Politics Under Suharto: Order, Development and Pressure for Change, Routledge, London and New York.

Walters, P. (1996), '10-year Pact Expands Jakarta Defence Ties', The Australian, 15 November.

Helpful comments from an anonymous referee are gratefully acknowledged. 